\title{
Euro area reform preferences of Central and Eastern European economic experts
}

\author{
Sebastian Blesse ${ }^{1}$ - Annika Havlik ${ }^{1,2}$. Friedrich Heinemann ${ }^{1,3}$
}

Published online: 21 February 2020

(c) The Author(s) 2020

\begin{abstract}
This study explores the positions of economic experts from Central and Eastern European (CEE) Member States in the euro reform debate. Given the dominant voices from French and German politicians and academics in the European discourse, there is an obvious neglect for the positions of CEE countries. Our study tries to fill this gap with a large survey among economic expert communities in all CEE countries conducted in spring 2019. We compare euro reform preferences to benchmarks of surveyed experts in France, Germany, and Italy. We discuss implications for the ongoing euro area reform with a particular focus on several non-euro members' growing reluctance to introduce the common currency. We argue that only a balanced reform package that combines solidarity with debt self-responsibility could foster the euro's appeal in the CEE region.
\end{abstract}

Keywords Euro reform debate · European Integration · Central and Eastern Europe · Expert survey

JEL Classification A11 $\cdot$ E63 $\cdot$ H63

Friedrich Heinemann

friedrich.heinemann@zew.de

Sebastian Blesse

sebastian.blesse@zew.de

Annika Havlik

annika.havlik@zew.de

1 ZEW - Leibniz Centre for European Economic Research, L7,1, 68161 Mannheim, Germany

2 University of Mannheim, Mannheim, Germany

3 University of Heidelberg, Heidelberg, Germany 


\section{Introduction}

A variety of reforms has been implemented to improve the institutional set-up of the euro area over the last decade. ${ }^{1}$ Nevertheless, the political and academic reform debate remains intense and the future of the euro area is unclear. There is a large consensus that the Economic and Monetary Union (EMU) is still a "half-built house" (Bergsten 2012). Much less consensus exists on the priorities for the direction of additional reforms. Ideas for the next steps are diverse; they comprise various suggestions for new stabilization tools that shield EMU members against asymmetric shocks, more refined and credible fiscal rules, suggestions for new sovereign financing tools, and blueprints for sovereign insolvency procedures (Dolls et al. 2016).

One striking feature of the ongoing debate is that it is characterized prominently by contributions from larger euro countries from Western Europe. Both politicians and economists of countries like France and Germany are highly active and influential in this debate. For example, the so-called " $7+7$ report" by seven French and seven German economists (Bénassy-Quéré et al. 2018) was an important and influential academic initiative to impact the EMU reform debate. On the political level, the joint "Meseberg Declaration" of the French and German governments with its section on EMU reforms from June 2018 is an example how large Member States in the West formulate joint positions that tend to set the agenda for further reform negotiations (Press and Information Office 2018). By contrast, smaller EU Member States and even more Member States from Central and Eastern Europe (CEE) seem to be much less visible and influential.

Given this Western European dominance, we want to elicit the preferences of Central and Eastern European (CEE) Member States in the debate on the reform of the euro area. We base our analysis on a unique database. We are able to assess the EMU reform preferences of CEE economic experts compared to France, Germany, and Italy based on a large and comprehensive survey of more than 1800 economists that was in the field in spring 2019. With this database, we are the first to map expert communities in all CEE EU Member States relative to their colleagues in the three reference countries. This comparison covers a range of important EMU reform topics.

Expert opinions are a relevant source of information to identify a country's reform preferences. Experts often come from the same academic elites as a country's politicians. They serve as advisors to national decision makers and thus

\footnotetext{
${ }^{1}$ Fiscal and macroeconomic governance rules have been refined and the rules of the Stability and Growth Pact (SGP) have been strengthened. The European Stability Mechanism (ESM) has been established as a source of liquidity for countries that lose capital market access and are ready to accept its conditions. On top of that, the European Central Bank (ECB) has effectively stepped into the role of a lender of last resort through the Outright Monetary Transaction (OMT) program. So far, OMT has never been activated but its mere existence has contributed to restoring trust in the markets for sovereign euro bonds. A banking union has been set up with a European supervision of large banks under the responsibility of the ECB and the establishment of a European Banking Resolution Mechanism. For more detailed information on reform efforts see Lane (2012) and Copelovitch et al. (2016).
} 
shape a government's position to some extent. More directly, economists can prepare or even take policy decisions themselves if they hold relevant positions like at central banks, fiscal councils or if they serve in ministries or turn to politics themselves (Hirschman and Popp Berman 2014). However, causality can run into both directions. Experts could have an impact on their own country's position. Or, alternatively, experts may simply take up the dominant views in their country as they are exposed to the same national media and national interests as ordinary citizens. Hence, their economic policy preferences might also mirror their countries' interests and public discourse to some extent.

Macroeconomic and European integration research has started to pay attention to the national heterogeneity of economists' positions in a few studies. De Ville and Berckvens (2015) conduct a survey on EMU reforms among euro area academic experts. They claim to identify an outsider-role of German economists, who are skeptical of any proposal moving the EMU in the direction of a fiscal union built on more fiscal stabilization mechanisms and mutual fiscal guarantees. However, the survey's sample size is limited (about 250 responses) with only a few responses from CEE countries, mainly from Slovenia. Moreover, the survey disregards crucial euro reform dimensions like a sovereign debt restructuring mechanism. Potrafke and Reischmann (2016) link economists' survey responses on a possible Greek exit from the euro to their countries' characteristics. They find that experts from countries with lower creditworthiness are more opposed to Greece leaving the euro than experts from countries with sound public finances. Asatryan et al. (2019) test for a national imprint in the estimation an important fiscal policy input - the fiscal multiplier. They show that the researcher's national background, proxied by her country's government-spending-to-GDP ratio is positively related to her estimate of the fiscal multiplier.

While empirical studies for experts are still rare, there exists more evidence on the positions of EU governments and politicians on EU and EMU reform. The "EMU Positions" dataset from Wasserfallen et al. (2019) describes Member States' positions in recent euro reform negotiations. Lehner and Wasserfallen (2019) find that these negotiations have been dominated by a one-dimensional conflict between Southern countries advocating more fiscal transfers and Northern countries prioritizing fiscal discipline. CEE countries have heterogeneous positions but often align with the Northern coalition stressing fiscal discipline. Insights on EU and EMU preferences for Germany, France, and Italy are provided by Blesse et al. (2019), who conduct a survey among the members of the three countries' national parliaments. Their results point to a rather isolated position for Germany, as they find a larger consensus between Italian and French politicians, while Germans more often disagree with their French and Italian colleagues.

Against the only gradually emerging empirical literature on EU expert reform preferences, our contribution can be summarized along three dimensions. First, we provide insights on EMU reform preferences of national expert communities in $\mathrm{CEE}$ countries on the basis of the largest euro-related expert survey that exists so far. This first contribution is of a descriptive nature and is valuable information as such, which allows to map the diverse positions of CEE countries across the reform space. 
Second and more analytically, we look at the emerging profile of expert preferences in the light of country characteristics to uncover a possible link between expert positions and their country's interests. Pisany-Ferry (2018) explains diverging economic positions between the European North and South as driven by both a "battle of interests" and a "battle of ideas". According to the "battle of interests" view, positions differ because they reflect different national self-interests. For example, a highdebt euro country will support mutual guarantees and a low-debt country will be rather opposed. According to the "battle of ideas" view, national positions are rather influenced by different economic school of thoughts with the prominent example of the French interventionism versus the German "Ordo-Liberalism" (Brunnermeier et al. 2016).

Third, we are able to draw conclusions for euro area reform strategies that would be able to make Europe's currency more appealing for CEE non-euro countries given the evidence that the appeal of Europe's common currency has strongly declined over the last decade in non-euro CEE countries (Roth et al. 2019).

For the first contribution, the mapping of preferences, key results are as follows: CEE economists outside the euro area are less enthusiastic about the benefits of the euro than experts from euro countries. CEE countries are significantly less supportive than France and Italy on more EU competencies in taxation. On reforms that entail more redistribution, expert preferences differ between richer and poorer countries. CEE expert communities are receptive towards new stabilization tools like a European unemployment insurance scheme. On Eurobonds, experts from CEE countries are often undecided, only poorer non-euro countries (Romania, Bulgaria, and Croatia) show a clear support, albeit not at the Italian level. Survey participants from the CEE countries often line up with German experts in their resistance to a relaxation of the Stability and Growth Pact (SGP). On the debate about sovereign debt restructuring mechanisms, the divide is clearly between Germany and CEE on the one hand (very supportive), and France and Italy on the other hand (only mildly supportive). Finally, eastern economists back both the European Deposit Insurance Scheme (EDIS) and the ECB's asset purchases.

On the second contribution, the link between positions and national interests, we argue that a substantial part of the described heterogeneity is consistent with country interests. Economists from poorer CEE countries are more in favor of cross-country redistribution and Eurobonds than those from more advanced economies. The resistance against a weakening of the SGP is particularly large in the richer CEE countries. Likewise, CEE positions on European tax competencies (rejection) and a sovereign debt restructuring mechanism (support) correspond to country characteristics, i.e., the low effective corporate tax rates and the low public debt level (compared to countries like Italy and France). Thus, we find ample evidence for the "battle of interest" view also in the cross-country heterogeneity of CEE expert views.

Relating to the third contribution that relates to EMU reform implications, one insight is that a further euro enlargement will depend on the new shape of euro institutions. A balanced reform that reconciles effective macroeconomic stabilization with credible no-bailout institutions could make euro accession of EU Member States like Poland, Hungary or the Czech Republic more likely. Conversely, given these countries' stable convergence path and more favorable fiscal development, it 
is unlikely that they could join a single currency that entails far reaching fiscal and monetary guarantees also for Member States with a debt overhang. This conclusion is particularly supported by the broad CEE expert support for a sovereign debt restructuring mechanism for the euro area.

In Sect. 2, we comprehensively screen the fiscal and economic situation of CEE countries to assess these countries' specific needs and preferences for the further evolution of euro area institutions. Section 3 describes our survey and Sect. 4 presents its results. Section 5 concludes and discusses avenues for comprehensive euro area reform that could pave the way into the euro for most CEE countries.

\section{Interests and incentives of CEE countries for euro area reforms}

In this section, we briefly assess the current state and developments in CEE countries for the following aspects: euro area membership-state and prospect, the economic convergence process, the cyclical volatility and labor market situation, the fiscal situation, as well as the corporate tax competitiveness. These country features will provide a benchmark when assessing the consistency of expert EMU preferences with their home countries' interests.

\subsection{Euro area membership: state and prospect}

The Baltic countries, Slovenia, and Slovakia have introduced the euro while the Czech Republic, Poland, Croatia, Bulgaria, Hungary, and Romania have not yet acceded to the common currency and, in the legal terminology, are "Member States with a derogation" (Art. 139 TFEU). Slovenia and Slovakia joined the euro area first in 2007 and 2009 respectively, while the Baltic countries followed afterwards with Estonia (2011), Latvia (2014), and Lithuania (2015). In all CEE euro members, public support for the euro is significant and has grown since accession to the monetary union (Roth et al. 2016).

Although the introduction of the euro is an ultimate goal of EU membership and EU Member States with a derogation are obliged to join once they meet the convergence criteria, most eastern non-euro countries are currently not considering to join the EMU with the exception of Croatia, Romania, and Bulgaria (see Table 1). The Czech Republic, Poland, Hungary, and Romania still have free- or managed floating exchange rates. Reasons for not entering the euro area are quite heterogeneous, ranging from domestic reasons, like insufficient economic convergence over a lacking perceived attractiveness of euro membership, to an unresolved institutional reform agenda (Backé and Dvorsky 2018).

Bulgaria and Croatia intend to enter the European Exchange Rate Mechanism (ERM II) in the foreseeable future, which would put the exchange rates of their national currencies in a narrowly defined bandwidth to the euro and would further their integration to the euro area. Bulgaria already pegs its national currency to the euro and thus has already fully given up an independent monetary policy. Meanwhile, Romania has prepared a draft plan to adopt the ERM II, 


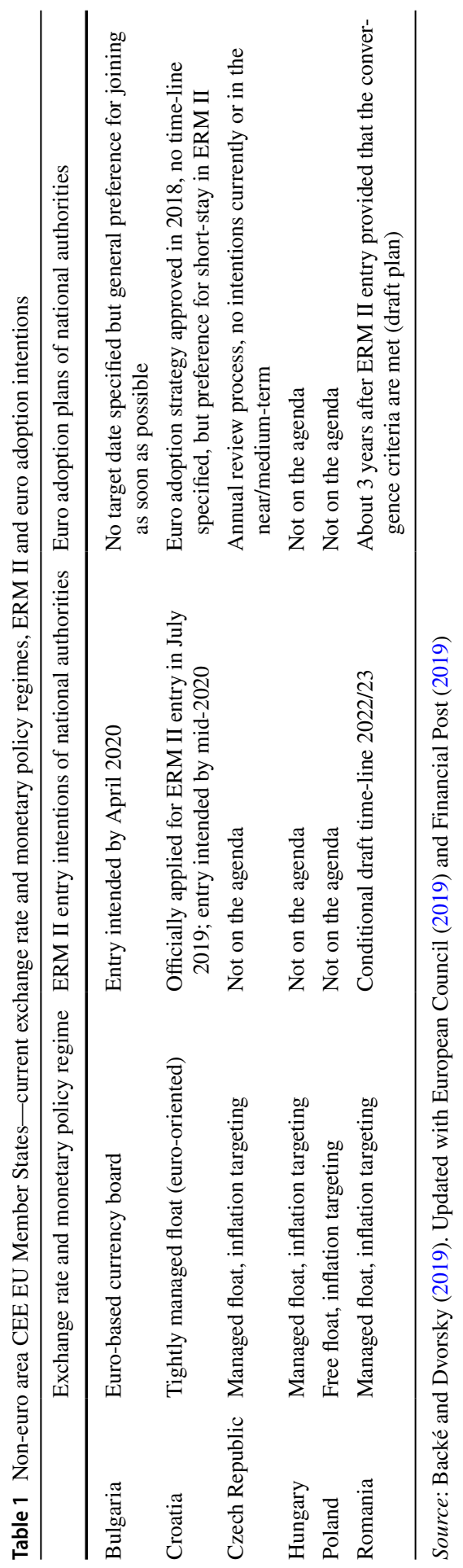


which has not officially been confirmed yet, though the country hopes to adopt the euro in 2024 (Euractiv 2019). Croatia has officially applied for membership in ERM II in July 2019 (European Council 2019).

\subsection{Convergence process and net-beneficiary status in the European Union}

Regardless of euro adoption, all Eastern Member States underwent significant economic growth from the early 1990s to this day. In studies analyzing time periods before 2010, the catch-up process of CEE countries is not visible (see, e.g., Borsi and Metiu 2015). Studies using more recent data confirm the convergence process of CEE countries (see, e.g., Diaz del Hoyo et al. 2017). However, real income convergence is diverse across CEE countries, with a GDP per capita (in purchasing power parities) ranging from 49.3 to $89.4 \%$ of the EU28 average in Bulgaria and Czech Republic in 2017, respectively (Table 2). Similarly, Borsi and Metiu (2015) and Von Lyncker and Thoennessen (2017) find heterogeneous real income convergence of CEE countries.

The catch-up process has already progressed significantly for some CEE countries, such as the Czech Republic, Slovenia, Estonia, Lithuania, and Slovakia who have income levels of more than $75 \%$ of the EU average. For instance, in 2017, the Czech Republic (89\%) and Slovenia (85\%) have already surpassed the income levels of several Southern EU members, such as Greece and Portugal with 67 and $77 \%$ of the EU28 average, respectively (Eurostat 2019a). Hence, these CEE countries are closely behind Spain (92\%) and Italy (96\% of EU28 average) in terms of income levels. However, other CEE countries are still lagging further behind with income levels around two thirds of the EU28 average or less. Convergence seems to continue as recent favorable growth projections for the years 2019 and 2020 indicate (European Commission 2019).

For EMU reform positioning, these findings would suggest that an increasing number of CEE countries should not have a strong interest in an extensive new euro area transfer system, as they may become donor countries in any such system in the not too distant future. However, the support for the existing instruments in the EU budget should remain strong for a long time to come. So far, all CEE countries are still strong beneficiaries from EU funding as is clear from the net balances with the EU budget as a share of gross national income (Table 2).

Payments in cohesion policy adjust to increasing income only very slowly and with considerable lag. Therefore, the current net balance profile in the classical transfer instruments of Cohesion and Common Agricultural Policy will still characterize EU spending at least for the time period of the coming Multiannual Financial Framework 2021-2027. This should explain a strong interest of CEE countries to preserve these traditional European transfer instruments as they are and not compromise them for new euro area fiscal capacities with their unpredictable beneficiary profile. 


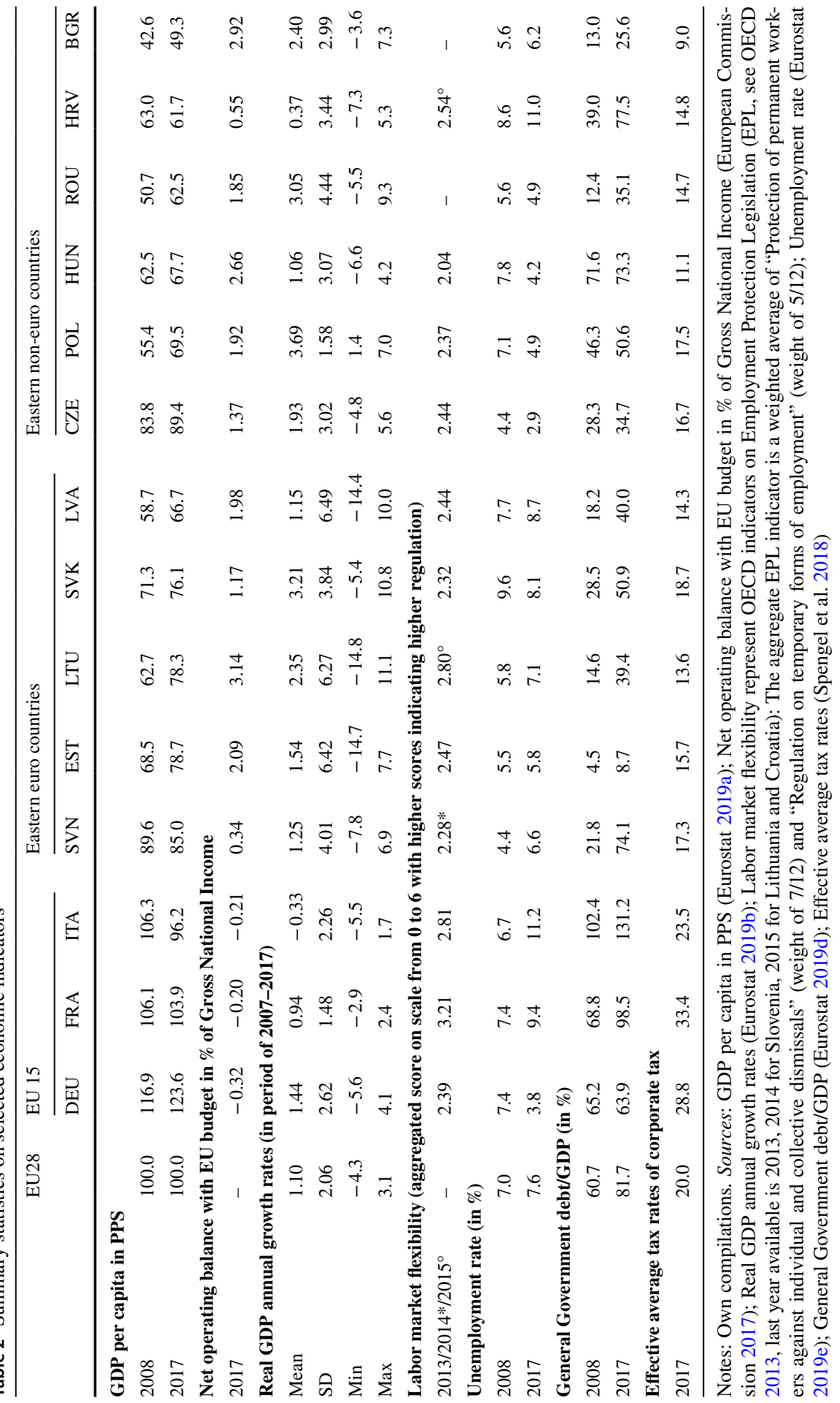




\subsection{Cyclical volatility and labor market situation}

Table 2 also shows indicators for GDP volatility over the crisis decade (2007-2017), i.e., the standard deviation as well as the minimum and maximum of real annual GDP growth. These numbers indicate that the decade of (average) economic convergence has also been characterized by a higher GDP volatility for most Eastern European countries compared to Western Europe. Only Poland had a stable GDP growth rates similar to the one of Germany, Italy or France. ${ }^{2}$

While the 2009 recession was deep in CEE countries, with particularly severe contractions of about 14-15\% of real GDP in the Baltic countries, economic growth recovered immediately after in 2010, and thus much faster than the rest of the euro area. After that, the region returned to a sustained growth path (Eurostat 2019a). Only Slovenia went through a longer transition path to growth with a second recession in 2012/2013 (Backé and Dvorsky 2018). It is worth mentioning that the Baltics achieved fast recovery while they were still outside the euro area but they stuck to their currencies' euro peg. Thus, these economies recovered without devaluing their currencies. Instead, strong frontloaded fiscal adjustments led to a massive internal devaluation (for the Latvian case, see Blanchard 2012).

Table 2 compares labor market flexibility of CEEs to the old Member States like Germany, Italy, and France by measuring flexibility with the Employment Protection Legislation (EPL) indicator of the OECD. It comprises weighted averages of detailed measures on labor regulation on permanent and temporary work. The final measure varies from 0 to 6 , where a low value indicates flexible EPL. The EPL measure suggests that most CEE countries have lower labor regulation than Italy and France but are comparable to Germany, which substantially deregulated its labor markets before the financial crisis. For instance, CEEs often have maximum unemployment benefit durations of about a year with relatively low benefit generosity levels compared to other European countries (OECD 2013).

In general, unemployment rates in CEE countries have reached levels below those of low-growth Western European countries like Italy of France. However, in some Eastern European economies, unemployment rates have not yet returned to the lower pre-crisis levels (Slovenia, Estonia, Lithuania, Latvia, Croatia, and Bulgaria). Heterogeneity among CEEs is large, with unemployment rates ranging from 2.9 to $11 \%$ in the Czech Republic and Croatia, respectively.

The evidence on growth volatility and insufficient employment growth accompanying the growth resurgence after the financial crisis illustrates that CEE economies might benefit from more effective stabilization tools for the EU and the euro area against asymmetric economic shocks.

\footnotetext{
${ }^{2}$ In fact, Poland was the only country that did not experience a recession during the financial crisis.
} 


\subsection{Fiscal situation}

Compared to Western Europe, CEE countries have a more favorable fiscal situation. Debt-to-GDP ratios are currently on average 42.6 and $49.5 \%$ for euro and non-euro CEE countries, respectively. This is well below other euro members and the EU28 as a whole (see Table 3). Only Croatia, Hungary, and Slovenia are somewhat above the $60 \%$ threshold imposed by the Maastricht criteria.

Also debt dynamics are more favorable in general, as current deficits are low compared to the EU28 average (Table 3), and the combination of low deficits with a low interest burden and high growth rates leads to a significant fall in debtto-GDP ratios. Five CEE countries run budget surpluses, while only Hungary, Romania, and Poland had deficits above the EU28 average in 2017.

At the moment, no CEE country violates the Maastricht 3\% deficit criterion (see Table 3). Indeed, most CEE countries rarely breach the 3\% threshold, with most violations during the financial crisis given the particularly severe recessions in the region. Poland and Hungary are the exceptions, with a large number of violations of the deficit rule from 2005 to 2017, i.e. 9 and 7 violations, respectively. Croatia only recently was able to bring its deficits below the respective Maastricht threshold. Estonia, in contrast, never violated the deficit rule. Moreover, CEE economies are characterized by rather low shares of total government spending to GDP (only Hungary is above the EU28 average in 2017; see Eurostat 2019c).

This overall favorable fiscal situation explains why several CEE countries, just like other Northern EU members, have no interest in a relaxation of fiscal rules, and are rather skeptical on new institutions that could be abused for bailing out high-debt euro members.

\subsection{Corporate tax competitiveness}

CEE countries, both inside and outside of the euro, have substantially lower effective average tax rates in corporate taxation than the EU as a whole. Given their highly competitive corporate tax policies, these countries should have a natural interest in keeping their national fiscal autonomy and position themselves against new EU competencies in tax harmonization. Possibly, CEE countries may be more open to policies that combat tax base erosion due to profit shifting in the European Union, such as the Common (Consolidated) Corporate tax base proposal from the European Commission (CCCTB or CCTB). The C(C)CTB would harmonize the corporate tax base across Member States but preserve national autonomy regarding tax rates. 


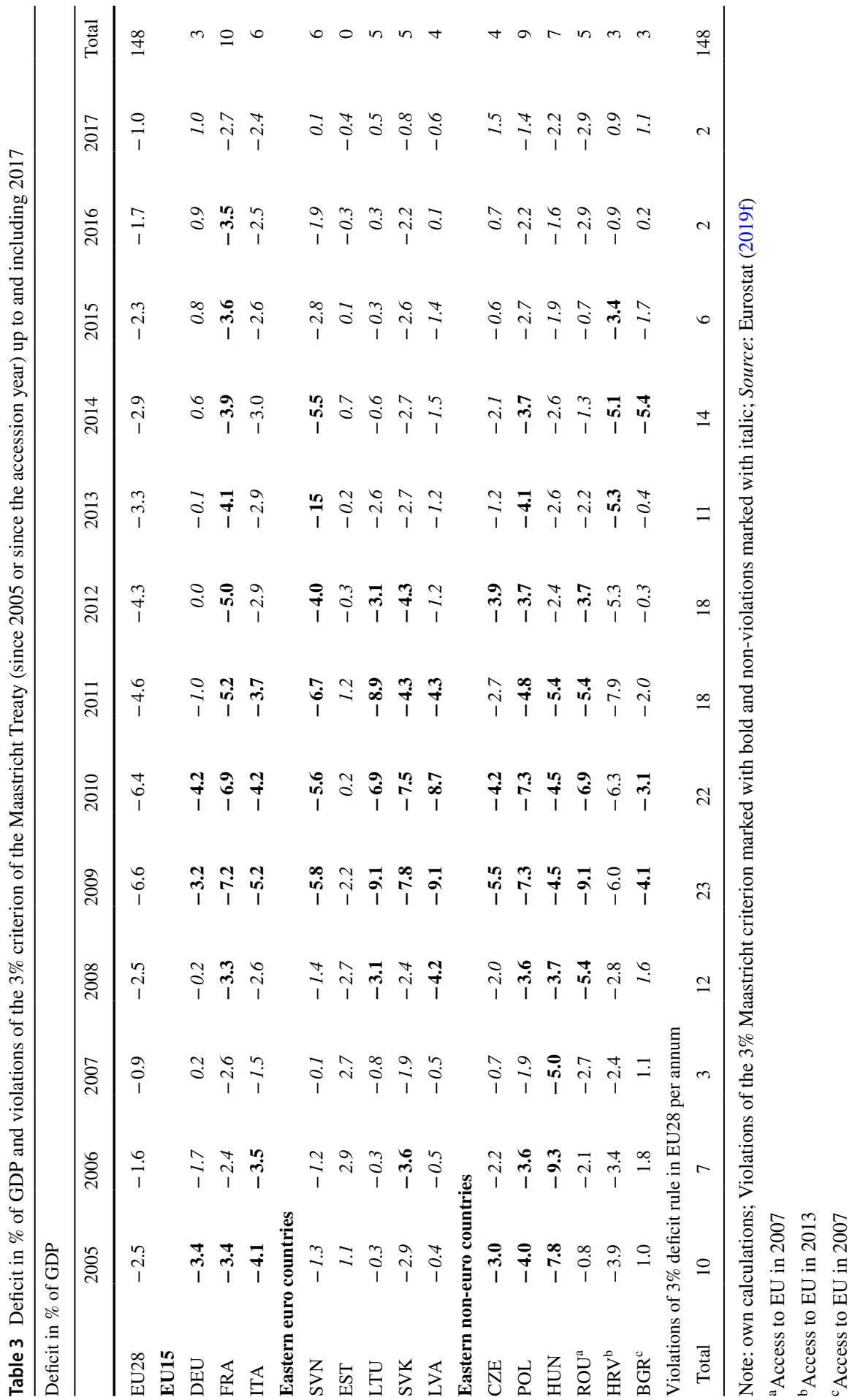


Box 1 Questionnaire structure of expert survey

\section{General attitudes on euro and economic policy \\ Economic benefits of euro (having/introducing the euro in my country) \\ EU competences \\ Tax policy \\ Redistribution}

Economic and Monetary Union (EMU)

European unemployment insurance

Eurobonds

Stability and Growth Pact (SGP)

Insolvency procedure for euro Member States

Asset purchase programme of ECB

Completion of Banking Union

Note: Own depiction

\section{The expert survey: structure, execution, and response rates}

In the following, we shed more light on EMU reform preferences of CEE countries by presenting the results of our self-conducted expert survey. Box 1 summarizes the survey structure (see "Appendix" for full questions).

We first ask how much the respondents support the euro. For euro member countries, we ask whether the euro is beneficial for the country's economy. In contrast, for non-euro countries, we ask whether the introduction of the common currency would be economically beneficial.

The second block of questions concerns preferences on tax centralization and increased redistribution among EU Member States. Increased transfers from rich to poor members could ultimately lead to a federal union with fiscal equalization in the EU. To some extent, such a mechanism is already in place through the cohesion policy financed from the European budget. ${ }^{3}$

The third block comprises of several questions on key EMU reform topics. First, we ask experts on their support for a potential European unemployment insurance scheme. This concept is prominently discussed as a way to cope with asymmetric economic shocks to euro area members. If countries give up an adjustable exchange rate, other adjustment instruments like fiscal insurance schemes could provide compensation for the affected countries.

Second, we ask questions on the desirability of Eurobonds and the asset purchase program by the ECB. These questions give an idea about the respondents' preferences with respect to how the euro area should cope with liquidity crises. Panicdriven vicious cycles on government bond markets, as in the recent euro area debt crisis, threaten to push countries into illiquidity even if these countries are not

\footnotetext{
${ }^{3}$ Conceptually, it is crucial to distinguish between stabilization/insurance against asymmetric shocks (without a permanent transfer element) and permanent equalizing transfer payments.
} 
insolvent. Various contagion risks and destructive loops such as increasing risk premia, financial instabilities, a downturn of the real economy or deteriorating public finances can have devastating consequences. In 2012, the ECB stepped in as a potential lender of last resort through the establishment of the Outright Monetary Transactions (OMT) program. Thus, it backed up the liquidity support provided by the ESM. We ask experts about their attitudes on the asset purchase program of the ECB. We also ask economic experts on their opinion regarding Eurobonds which are, by contrast, a very different solution for liquidity crises than asset purchases of the ECB. Specifically, Eurobonds provide liquidity through a common European bond that finances public debt of all Member States based on extensive mutual guarantees.

Third, we ask our participants about their attitudes regarding a potential relaxation of the SGP. The Maastricht criteria and the SGP in particular intended to incentivize fiscal sustainability of EU Member States.

Fourth, we ask whether there should be an explicit sovereign insolvency procedure for euro Member States with unsustainable debt. Debt is unsustainable in cases of outright insolvency, i.e., if there is a public debt overhang in excess of the taxing and repayment capacity of a country which is also beyond a temporary liquidity crisis. If the debt overhang is not (sufficiently) addressed through transfers from European institutions or other Member States, public debt has to be restructured. A sovereign insolvency procedure can provide mechanisms and rules to manage the restructuring in an orderly way (Fuest et al. 2016; Destais et al. 2019). ${ }^{4}$ Hence, the EMU's way to deal with insolvency implies a decision on the intensity of market discipline.

Finally, we survey the experts on their preferences regarding the completion of the Banking Union through the establishment of the EDIS. While EDIS may increase the resilience of the Banking Union with respect to destructive panics of depositors (Béranger and Laurence 2015), opponents are afraid of a collectivization of non-performing loans or excessive sovereign exposure in national banking systems of the EU.

We fielded our expert survey on economists across EU Member States in February 2019 and received answers from February to April 2019. The survey was conducted as an online survey with two email reminders for participants who did not answer and did not explicitly decline participation. The survey was translated in the respective mother tongues for German, French, and Italian participants, though the email also included a second version of the invitation in English. Invitation emails and the web-survey for all CEE countries were in English.

Our sample consists of a comprehensive list of economists in the three largest "old” EU Member States (Germany, France, and Italy), as well as all "new" Member States from CEE countries (Czech Republic, Poland, Lithuania, Croatia, Bulgaria,

\footnotetext{
4 Also the (non-)existence of a credible debt restructuring option has incentive effects for borrowers and creditors. A credible insolvency procedure for sovereigns will make creditors more cautious in providing capital to countries with a critical debt level. Thus, issuing new debt becomes more expensive for debtors.
} 
Estonia, Latvia, Hungary, Romania, Slovenia, and Slovakia). Although we are mainly interested in the variation of attitudes on EU and euro area reforms from new Member States, we include German, French, and Italian expert views as the benchmark against which (heterogeneous) views from CEE countries can be evaluated.

For CEE countries, we retrieved the relevant participant list by searching for members of all economics departments, institutes, and research centers (EDIRC) in the respective countries, which are listed on Repec.org (Research Papers in Economics) as of July 2018. EDIRC indexes economic institutions with links to their members and publications listed on RePEc. Since our RePEc search was for institutions and we subsequently obtained author data from the institution websites, not all survey participants from new Member States are necessarily listed on RePEc and are not necessarily economists (but only work for an economics institution) in that respective country.

Since Germany, France, and Italy have arguably much higher numbers of academic and non-academic economists, we sampled only the top $25 \%$ of RePEc authors listed at institutions residing in these countries. ${ }^{5}$ Altogether, we surveyed 7332 economists from 14 EU countries. The number of responses and response rates for each country can be found in Table 4 . We received answers from more than 1800 experts, which amounts to an overall response rate of about $25 \%$. Individual participation rates per country range from $19 \%$ in France to $38 \%$ in Italy. All CEE countries have sound response rates from 21 to $31 \%$ of all interviewees (see Table 4 for details).

\section{Survey results}

Table 5 reports means and standard deviations (SD) for all survey questions and countries. Points refer to the answer scale of -4 to +4 , where a higher score means a larger agreement with the question's position (for precise question formulation, see "Appendix"). While the mean indicates the average position of a country's expert community, the SD is informative as to the consensus within the national community (with a low/high SD indicating a high/low consensus).

\subsection{General attitudes on euro and economic policy}

First, we asked survey participants in euro area countries whether they perceive euro membership as economically beneficial. We find that none of the national expert communities of the euro area seem to regret that their country has entered the common currency. This holds both for older members like Germany, Italy, and France, as well as the new entrants from the CEE region (Slovenia, Estonia, Lithuania, Slovakia, and Latvia), which all voice strong average support for euro membership.

In a similar vein, we asked economists from non-euro countries whether they think that the introduction of the euro would be economically beneficial. Economists

\footnotetext{
5 The lists can be found via https://ideas.repec.org/top/top.[Insertcountry].html (dated at December 2018).
} 


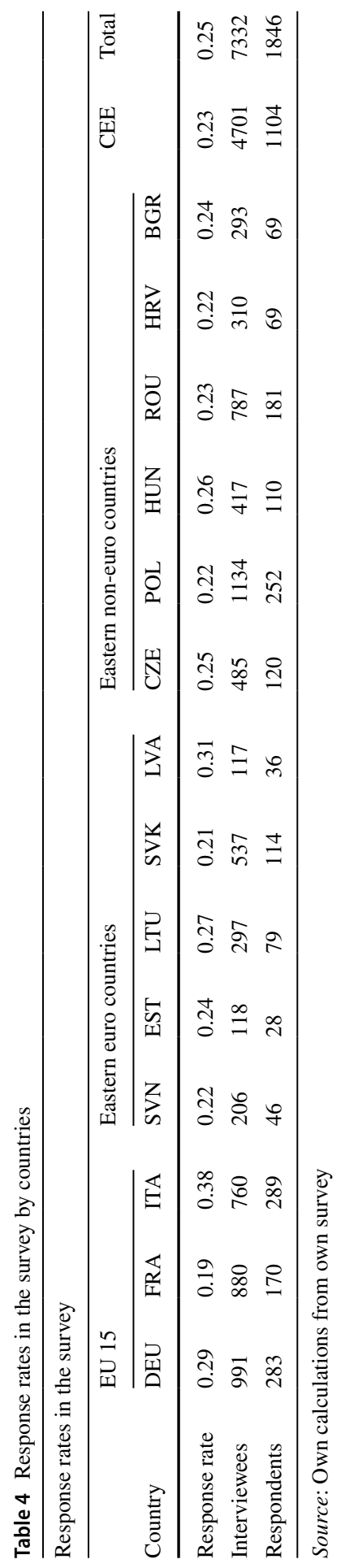




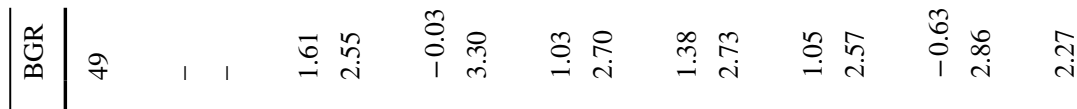

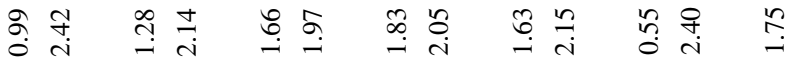

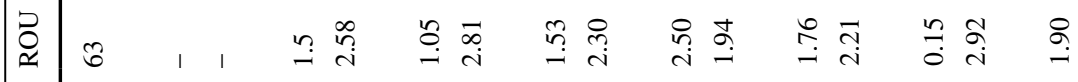

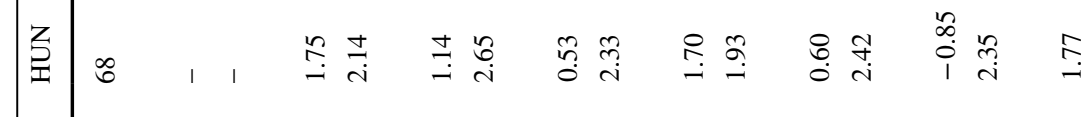

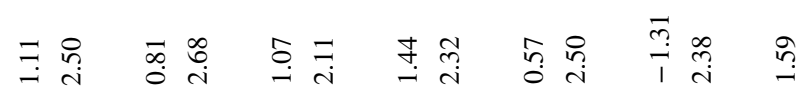

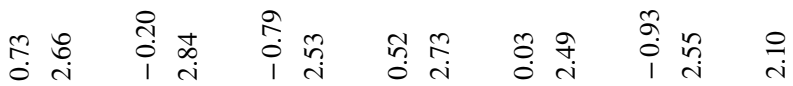

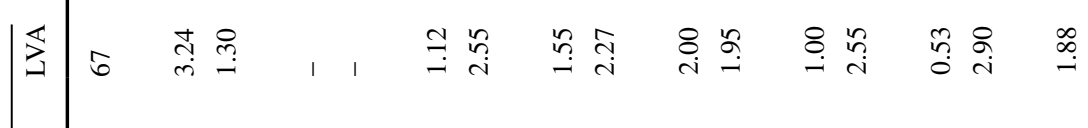

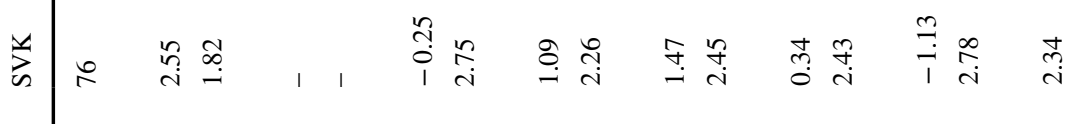

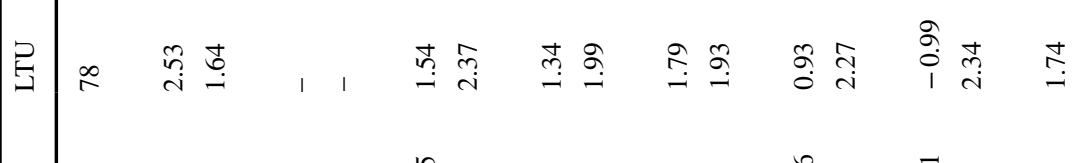

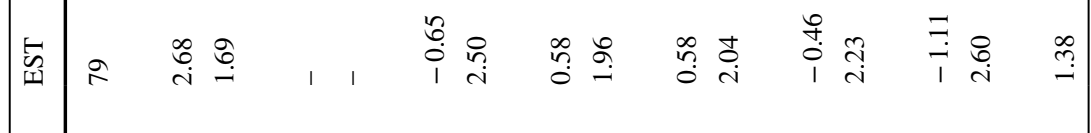

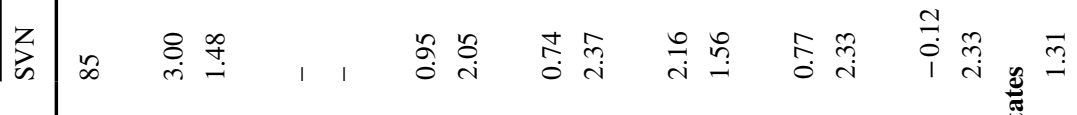

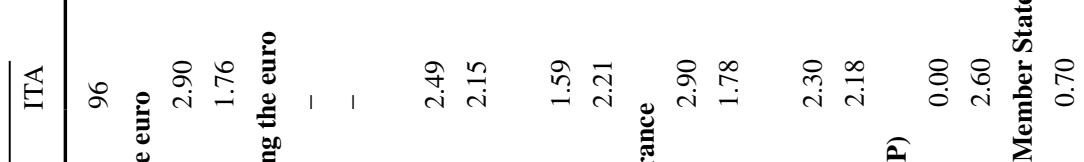

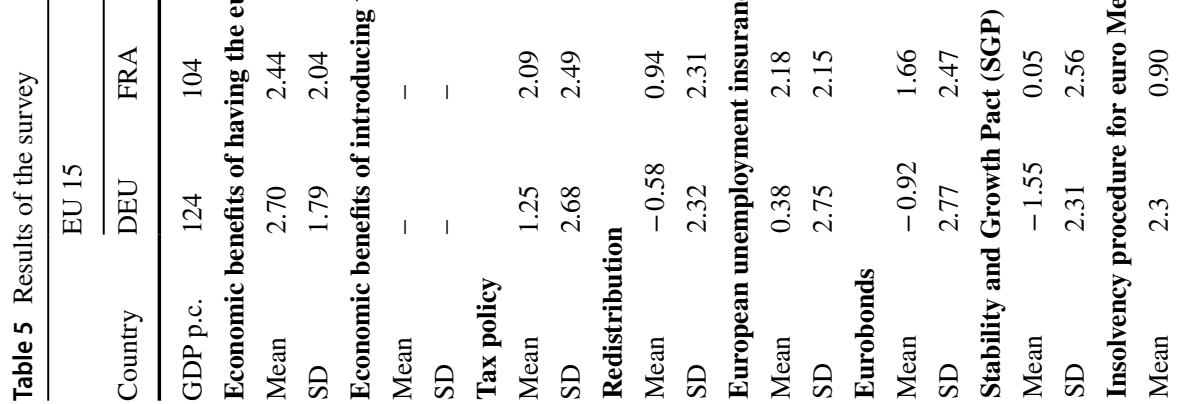




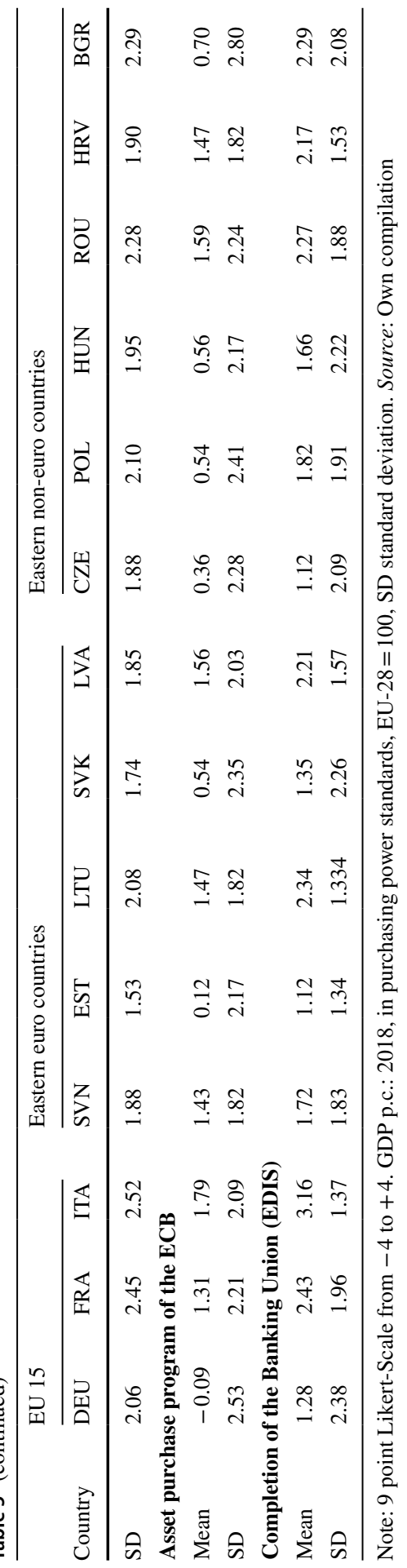


from non-euro CEE countries (especially Czech Republic and Croatia) are somewhat less enthusiastic about introducing the euro in their countries. However, average answers are positive and economists are generally supportive of a possible euro currency introduction in their respective home countries. Thus, economic experts in non-euro countries are clearly more in favor of a euro introduction than the population in general: Eurobarometer data reveal a declining support for the euro in the non-euro countries over the past decade with net support levels having turned negative for several countries (Roth et al. 2019).

\subsection{Tax centralization and redistribution}

Do economic experts want to delegate more competences from the national to the European level? Regarding more EU competencies in taxation (through qualified majority instead of unanimity), CEE countries are significantly less supportive than France and Italy. Most CEE countries line up well with the German position and are only weakly supportive of facilitated EU-legislation on union-wide tax issues. Slovakia, the Czech Republic, and Bulgaria are undecided, while Estonia slightly rejects the proposal. Overall, this corresponds to the prediction that the low-tax CEE countries should be more cautious in handing over tax competencies to Brussels.

Moreover, expert communities in poorer countries are more supportive for an increase of redistributive transfers from rich to poor countries in the EU. The support is relatively high (average scores around 1.5 or more) in Italy, Lithuania, Latvia, Romania, and Croatia. Economists in Germany and, even more so, in the Czech Republic, are rather skeptical. Other CEE countries provide only mild support for progressive transfers across EU Members. The fact that CEE experts are by no means more supportive for redistribution than in a country like Italy corresponds to a forward-looking perspective on relative income levels in the EU. If the currently stable growth of income levels in CEE countries continues, they may soon overtake several western non-converging EU countries and would then cease to be beneficiaries of more intense redistribution.

\subsection{European Monetary Union}

Our first EMU-related question asked for the perceived need of fiscal stabilization against asymmetric shocks and mentions the example of a European unemployment insurance scheme. Both French and Italian economists strongly support more fiscal stabilization of this kind, while participants from Germany are only slightly supportive. Experts in Estonia and the Czech Republic align well with the almost undecided German view, while all other countries support risk sharing through a common unemployment insurance scheme in the euro area. CEE support is somewhat weaker, however, than in France and Italy, with the exception of Romania, Slovenia, and Latvia. The friendly perspective on institutional reforms like a European unemployment insurance scheme corresponds to CEE members' national interests given their recent history with respect to volatility of economic growth and unemployment rates over the last decade. 
Second, we surveyed the views on debt mutualization in the EMU with a question on Eurobonds. Eurobonds can provide liquidity for euro countries that lose market access. At the same time, they can imply a transfer from countries with high to countries with low creditworthiness. As expected, we observe that German economists reject the proposal, while there is clear support for Eurobonds among the French and even more so among Italian experts. Expert communities in most eastern Member States, however, show less support than participants from France and Italy. Only the poorer non-euro countries in the region (Latvia, Romania, Croatia, and Bulgaria) reach average scores of about one or above. Interestingly, Estonians line up with German economists and reject debt mutualization through the introduction of Eurobonds. The lack of Eurobond enthusiasm in the east is consistent with the more sound public finances of CEE countries and a perception that these countries are unlikely to need to safeguard their budgets through mutual financial guarantees with other Member States.

Third, we asked experts about their views on the SGP and their support for relaxation of the SGP. German economists reject a softer SGP while experts from France and Italy are essentially undecided on the matter. Economists in most CEE countries appear to be often well in line with the German expert position. Only Latvia, Romania, and Croatia have positive means (i.e., supportive of a relaxation) while Slovenia is negative but close to zero. As argued above, the high compliance of CEE countries with the SGP in the recent past could explain this observation.

Fourth, we investigated preferences on an insolvency procedure for euro Member States with unsustainable debt. Participants from all countries (including all euro and non-euro CEE countries) support such an explicit sovereign debt procedure, with German, Slovakian, and Bulgarian economists showing the strongest support on average. Remarkably, French and Italian economists are also somewhat supportive of an explicit mechanism for debt restructuring, but with lower average scores than Germany and all CEE countries. Thus, on that issue, the divide, if any, is rather between Germany and CEE countries on the one side, and France and Italy on the other side. This finding is also consistent with a "battle of interest" view in that CEE countries have a more sustainable public debt situation and, therefore, are less concerned about the possible risks of a sovereign insolvency.

Fifth, we surveyed which stance economists take on the asset purchase program of the ECB. The results suggest that experts from most countries are supportive of the active role of the ECB and want it to continue. Support is especially strong among experts in France, Italy, Slovenia, Lithuania, Latvia, Romania, and Croatia. Support is the weakest in Germany, where the average response is even slightly negative, and other countries such as Estonia, the Czech Republic, Poland, and Hungary which are undecided.

Finally, participants had to answer whether they support the completion of the European Banking Union through EDIS. Interestingly, this policy reaches unanimous support across expert communities in all countries. Although CEE countries are supportive, the enthusiasm for EDIS does not reach the Italian level in any other country. The most supportive CEE countries (Lithuania, Latvia, Romania, Croatia, and Bulgaria) line up well with the average support level of French experts. 


\section{Euro reform conclusions}

The results of our expert survey in CEE countries suggest that economists' support for euro area reforms corresponds to their countries' interests given the economic and fiscal situation of the respective country. The acceptance of the euro among economic experts is generally higher in euro Member States than in non-euro Member States. This corroborates with findings of Roth et al. (2016 and 2019) where euro support among residents of euro countries was increasing since the financial crisis while it decreased strongly for non-euro countries including CEE countries. Recent Eurobarometer polls indicate that among the CEE Member States only Romania has popular support for a euro adoption while all other countries lost popular support (European Commission 2018).

Experts in CEE countries are in general more cautious with respect to more EU centralization and coordination. Economic experts in CEE countries are much less supportive of a larger EU role in corporate taxation than their western colleagues-a finding clearly consistent with national interests given low tax rates in CEE countries. Preferences regarding redistributive transfers across Member States does not follow East-West divisions but is well in line with the income levels of the respective country. Specifically, poorer countries show higher support of more redistributive transfers in the EU.

For EMU-related innovations that could provide more stabilization (European unemployment insurance) or increase trust in national banking systems (EDIS), positions of most CEE countries are friendly but often not that as supportive as the Italian benchmark. This might mirror the demand for macroeconomic insurance given past large GDP fluctuations but at the same time concerns on the risks of future unfavorable transfer patterns within the euro area.

An insolvency procedure for sovereigns in the euro area is welcomed in all CEE countries. This finding is consistent with a perception that EMU membership increasingly entails a participation in guarantee and transfer schemes that support or might eventually even bail out high-debt countries. From the perspective of rather fiscally sound countries with a good growth performance (outside the euro), this perception makes euro membership less attractive. This interpretation is consistent with our evidence that experts particularly from more advanced non-euro countries are less supportive of a SGP relaxation or more redistribution. They also want to see a credible insolvency procedure in place for euro countries that suffer from a debt overhang.

Our cautious prediction is that a one-sided mix of reforms could also cement the derogation status of the more advanced CEE countries outside of the euro. A reform that, in an unbalanced way, prioritizes fiscal solidarity without improving the incentives for a prudent growth and budgetary policy will hardly be met with large applause in most parts of the CEE region. Only comprehensive and balanced package deals are likely to increase the euro appeal for these countries. Given the positioning of national experts in our survey described above, reform packages that should be attractive from the eastern perspective should include the following elements. 
A viable insolvency procedure for insolvent euro countries could be an important safeguard against the likelihood of future bail-outs. Its establishment would signal that unsustainable debt levels will not provoke a transfer solution, but will be solved through write-offs for private creditors. Under the status quo, crucial elements are missing that could make any such debt restructuring a credible option for larger euro countries that still appear "too big to fail".

New stabilization tools that help euro members to cope with transitory negative growth and unemployment shocks should be a further appealing element of a comprehensive euro reform package given some CEE economies' experience with high GDP and unemployment volatility. Thus, the more negative position on permanent transfers and debt bail-outs must be clearly distinguished from a larger support for short-run stabilization tools. Stabilization tools, however, are an important example for the "all or nothing" principle of a big bang reform package. Ambitious stabilization tools without a credible insolvency procedure run the risk of degenerating into a mechanism for permanent transfers in a new debt crisis. Hence, new stabilization tools should be particularly appealing to CEE countries in combination with an insolvency procedure, but much less so in isolation. In addition, their design should credibly exclude permanent transfers.

Finally, with calls for more tax centralization there is also one "no go" element in the reform package: CEE countries have been using their national tax policy autonomy to make their locations more competitive for corporate investment. Tax harmonization that would cut back national autonomy within the EU or within the euro area will be seen very critically in the region as this would be perceived as limiting a legitimate and important freedom in national economic policy.

Acknowledgements Open Access funding provided by Projekt DEAL. We thank the Brigitte Strube Foundation for financial support. We acknowledge the comments of an anonymous referee and Peter Backe on CEE euro adoption intentions and thank Peter Buchmann for technical support with the survey. Victor Casemiro Wille Campos, Joshua Handke, Tobias Liebe, Théo Roudil-Valentin, Lucy Tretter, and Fabian Wagner provided excellent research assistance.

Open Access This article is licensed under a Creative Commons Attribution 4.0 International License, which permits use, sharing, adaptation, distribution and reproduction in any medium or format, as long as you give appropriate credit to the original author(s) and the source, provide a link to the Creative Commons licence, and indicate if changes were made. The images or other third party material in this article are included in the article's Creative Commons licence, unless indicated otherwise in a credit line to the material. If material is not included in the article's Creative Commons licence and your intended use is not permitted by statutory regulation or exceeds the permitted use, you will need to obtain permission directly from the copyright holder. To view a copy of this licence, visit http://creativecommons.org/licen ses/by/4.0/.

\title{
Appendix: Questionnaire
}

\author{
Do you agree with the following statements?
}

\section{General attitudes on euro and economic policy}

\section{Economic benefits of euro}


Having the euro in "MY COUNTRY" as the official currency is economically beneficial.

Disagree
\begin{tabular}{|l|l|l|l|l|l|l|l|l|}
\hline$\square-4$ & $\square \cdot 3$ & $\square-2$ & $\square-1$ & $\square$ Agree & \\
\hline
\end{tabular}

\section{OR}

Introducing the euro in "MY COUNTRY" as the official currency would be economically beneficial.

Disagree
\begin{tabular}{|l|l|l|l|l|l|l|l|l|}
\hline$\square-4$ & $\square-3$ & $\square-2$ & $\square-1$ & $\square$ Andee \\
\hline
\end{tabular}

\section{EU competencies}

\section{Tax policy}

The European Council should be able to vote on tax issues with a qualified majority instead of unanimity (e.g. common caps or floors for corporate taxes binding for Member States).

Disagree
\begin{tabular}{|l|l|l|l|l|l|l|l|l|}
\hline$\square-4$ & $\square-3$ & $\square-2$ & $\square-1$ & $\square 0$ & $\square+1$ & $\square+2$ & $\square+3$ & $\square+4$ \\
\hline
\end{tabular}

\section{Redistribution}

There should be more redistribution from richer to poorer EU Member States.

Disagree
\begin{tabular}{|l|l|l|l|l|l|l|l|l|}
\hline$\square-4$ & $\square-3$ & $\square-2$ & $\square-1$ & $\square$ Agree & \\
\hline
\end{tabular}

\section{European Monetary Union (EMU)}

\section{European unemployment insurance}

The EMU needs fiscal stabilization systems to insure Member States against asymmetric shocks (e.g. a common European unemployment insurance).

Disagree
\begin{tabular}{|l|l|l|l|l|l|l|l|l|}
\hline$\square-4$ & $\square \cdot 3$ & $\square-2$ & $\square-1$ & $\square$ Agree \\
\hline
\end{tabular}

\section{Eurobonds}

All euro countries are jointly liable for Eurobonds and all euro countries pay the same interest. The EMU should issue Eurobonds.

Disagree
\begin{tabular}{|l|l|l|l|l|l|l|l|l|}
\hline \\
\hline$\square-4$ & $\square \cdot 3$ & $\square-2$ & $\square-1$ & $\square$ Agree & \\
\hline
\end{tabular}




\section{Stability and Growth Pact (SGP)}

The SGP defines deficit and debt limits for EU Member States. The SGP inappropriately constrains fiscal policy in Member States and should be relaxed.

Disagree
\begin{tabular}{|l|l|l|l|l|l|l|l|l|}
\hline$\square-4$ & $\square \cdot 3$ & $\square-2$ & $\square-1$ & $\square$ Agree & \\
\hline
\end{tabular}

\section{Insolvency procedure for euro Member States}

There should be an explicit sovereign insolvency procedure for euro Member States with unsustainable debt.

Disagree
\begin{tabular}{|l|l|l|l|l|l|l|l|l|}
\hline$\square-4$ & $\square-3$ & $\square-2$ & $\square-1$ & $\square$ Agree & \\
\hline
\end{tabular}

\section{Asset purchase programme of ECB}

The European Central Bank (ECB) has taken a strongly active position in recent years by purchasing sovereign bonds of euro countries. This strongly active position of the ECB should continue.

Disagree
\begin{tabular}{|l|l|l|l|l|l|l|l|l|}
\hline \\
\hline$\square-4$ & $\square \cdot 3$ & $\square-2$ & $\square-1$ & $\square$ Agree & \\
\hline
\end{tabular}

\section{Completion of Banking Union}

For its proper functioning, the European Banking Union should be completed through the European Deposit Insurance Scheme (EDIS).

Disagree
\begin{tabular}{|l|l|l|l|l|l|l|l|l|}
\hline$\square-4$ & $\square-3$ & $\square-2$ & $\square-1$ & $\square$ Agree \\
\hline
\end{tabular}

\section{References}

Asatryan Z, Havlik A, Heinemann F, Nover J (2019) Biases in fiscal multiplier estimates. ZEW Discussion Paper 19-25, Mannheim

Backé P, Dvorsky S (2018) Enlargement of the Euro Area toward CESEE: progress and perspectives. Focus on European Economic Integration, Oesterreichische Nationalbank (Austrian Central Bank) 18(3):43-56

Backé P, Dvorsky S (2019) Enlargement of the Euro Area: taking stock and perspectives. Mimeo, New York

Bénassy-Quéré A, Brunnermeier M, Enderlein H, Farhi E, Fratzscher M, Fuest C, Gourinchas P-O, Martin P, Pisani-Ferry J, Rey H, Schnabel I, Veron N, Weder di Mauro B, Zettelmeyer J (2018) Reconciling risk sharing with market discipline: a constructive approach to Euro Area reform. CEPR Policy Insight No 91

Béranger A, Laurence S (2015) Banking union: mind the gaps. Int Econ 144:95-115

Bergsten CF (2012) Why the Euro will survive: completing the continent's half-built house. Peterson Institute for International Economics. https://piie.com/commentary/speeches-papers/why-euro-willsurvive-completing-continents-half-built-house. Accessed 22 Aug 2012

Blanchard O (2012) Lessons from Latvia. https://blogs.imf.org/2012/06/11/lessons-from-latvia/. Accessed 11 June 2012 
Blesse S, Bordignon M, Boyer PC, Carapella P, Heinemann F, Janeba E, Raj A (2019) United we stand?-Survey of French, German and Italian parliamentarians on EU and EMU reforms. ZEW policy brief Nr. 19-01, Mannheim

Borsi MT, Metiu N (2015) The evolution of economic convergence in the European Union. Empir Econ 48(2):657-681

Brunnermeier M, James H, Landau J-P (2016) The Euro and the battle of ideas. Princeton University Press, Princeton

Copelovitch M, Frieden J, Walter S (2016) The political economy of the Euro crisis. Comp Political Stud 49(7):811-840

De Ville F, Berckvens D (2015) What do Eurozone academics think about EMU reform? On broad support and German exceptionalism. Bruges Political Research Papers 41/2015

Destais C, Eidam F, Heinemann F (2019) The design of a Sovereign debt restructuring mechanism for the Euro Area: Choices and trade-offs. EconPol Policy Report 11

Diaz del Hoyo JL, Dorrucci E, Heinz FF, Muzikarova S (2017) Real convergence in the Euro Area: a long-term perspective. ECB Occasional Paper 203

Dolls M, Fuest C, Heinemann F, Peichl A (2016) Reconciling insurance with market discipline: a Blueprint for a European Fiscal Union. CESifo Econ Stud 62(2):210-231

European Commission (2017). EU expenditure and revenue 2014-2020. http://ec.europa.eu/budget/graph s/revenue_expediture.html. Accessed 9 May 2019

European Commission (2018) Eurobarometer 89.1. Brussels, March

European Commission (2019). Convergence criteria for joining. https://ec.europa.eu/info/business-econo my-euro/euro-area/enlargement-euro-area/convergence-criteria-joining_en. Accessed 9 May 2019

European Council (2019). Letter of intent. https://www.consilium.europa.eu/media/40282/letter-of-inten t.pdf. Accessed 4 July 2019

Eurostat (2019a) GDP per capita in PPS (Index (EU28=100)). https://ec.europa.eu/eurostat/tgm/table . do tab $=$ table\&init $=1 \&$ plugin $=1 \&$ language $=e n \& p c o d e=$ tec00114. Accessed 9 May 2019

Eurostat (2019b) Real GDP growth rate-volume. https://ec.europa.eu/eurostat/tgm/table.do?tab=table \&init $=1 \&$ language $=$ en $\&$ pcode $=$ tec $00115 \&$ plugin $=1$. Accessed 9 May 2019

Eurostat (2019c) General government expenditure by function: total general government expenditure as a percentage of gross domestic product (GDP). http://appsso.eurostat.ec.europa.eu/nui/show.do?datas et=gov_10a_exp\&lang=en. Accessed 9 May 2019

Eurostat (2019d) General government gross debt-annual data as a percentage of gross domestic product (GDP). https://ec.europa.eu/eurostat/tgm/table.do $? \mathrm{tab}=$ table \&init $=1 \&$ language $=$ en $\&$ pcode $=$ teina 225\&plugin=1. Accessed 9 May 2019

Eurostat (2019e) Unemployment by sex and age — annual average: total in percentage of total population. https://ec.europa.eu/eurostat/de/web/products-datasets/-/UNE_RT_A. Accessed 9 May 2019

Eurostat (2019f) Government deficit/surplus, debt and associated data: net lending (-)/net borrowing $(+)$ as a percentage of gross domestic product (GDP). http://appsso.eurostat.ec.europa.eu/nui/show. do?dataset=gov_10dd_edpt1\&lang=eng. Accessed 9 May 2019

Financial Post (2019) Bulgaria hopes to join euro zone 'waiting room' by end of April. https://business. financialpost.com/pmn/business-pmn/bulgaria-hopes-to-join-euro-zone-waiting-room-by-end-ofapril-minister. Accessed 31 Jan 2020

Fuest C, Heinemann F, Schröder C (2016) A viable insolvency procedure for Sovereigns in the Euro Area. J Common Market Stud 54(2):301-317

Hirschman D, Popp Berman E (2014) Do economists make policies? On the political effects of economics. Socio-Econ Rev 12(4):779-811

Lane PR (2012) The European sovereign debt crisis. J Econ Perspect 26(3):49-68

Lehner T, Wasserfallen F (2019) Political conflict in the reform of the Eurozone. Eur Union Politics 20(1):45-64

OECD (2013) Latest data on the OECD indicators of employment protection. http://www.oecd.org/emplo yment/emp/oecdindicatorsofemploymentprotection.htm. Accessed 23 July 2019

Pisany-Ferry J (2018) Euro Area reform: an anatomy of the debate. CEPR Policy Insight No 95

Potrafke N, Reischmann M (2016) How to handle the fiscal crisis in Greece? Empirical evidence based on a survey of economic experts. CESifo Working Paper No. 5860

Press and Information Office (2018) Meseberg declaration, renewing Europe's promises of security and prosperity, Berlin. 19.06.2018

Roth F, Jonung L, Nowak-Lehmann F (2016) Crisis and public support for the Euro, 1990-2014. J Common Market Stud 54:944-960 
Roth F, Baake E, Jonung L, Nowak-Lehmann DF (2019) Revisiting public support for the Euro, 19992017: accounting for the crisis and the recovery. J Common Market Stud 57:1262-1273

Spengel C, Schmidt F, Heckemeyer JH, Nicolay K, Bartholmeß A, Bräutigam R, Braun J, Buchmann P, Bührle T, Casi E, Dutt V, Fischer L, Harendt C, Olbert M, Pfeiffer O, Schwab T, Steinbrenner D, Stutzenberger K, Todtenhaupt M, Vay H, Werner A (2018) Effective tax levels using the Devereux/ Griffith methodology—update 2017. Project for the EU Commission TAXUD/2013/CC/120 Final Report 2017, Mannheim

Von Lyncker K, Thoennessen R (2017) Regional club convergence in the EU: evidence from a panel data analysis. Empir Econ 52(2):525-553

Wasserfallen F, Leuffen D, Kudrna Z, Degner H (2019) Analysing European Union decision-making during the Eurozone crisis with new data. Eur Union Politics 20(1):3-23

Publisher's Note Springer Nature remains neutral with regard to jurisdictional claims in published maps and institutional affiliations. 